\title{
Mind Your Grammar! - Learning English Grammar the Fun Way
}

\author{
Lilly Metom \\ Universiti Teknologi Mara, Sarawak Campus, Malaysia
}

lillymetom@sarawak.uitm.edu.my

Amelia Alfred Tom

Universiti Teknologi Mara, Sarawak Campus, Malaysia ameliaalfred@sarawak.uitm.edu.my

Saira Joe

Universiti Teknologi Mara, Sarawak Campus, Malaysia saira03@sarawak.uitm.edu.my

Doi:10.5901/jesr.2013.v3n7p402

\section{Abstract}

English has complicated sets of grammar rules, which make it a challenging language to master. Many non-native learners struggle with these rules and encounter difficulties in understanding them. Malaysian students, in particular, are unable to apply the different parts of speech and types of tense in English accurately in their speaking and writing. Hence, using the right approach to teach grammar is essential to help the students learn it effectively. This paper presents a survey study of an innovation project titled Mind Your Grammar!. It is a language board game, designed specifically for the beginner-level learners of English, both in schools and higher learning institutions. When learning grammar becomes a game, it takes away the monotony that appears to associate with it. Instead, the game aspect comes to the foreground where the learners believe that they are playing a game; thus, this will enable the language teacher to retain their interest without making them bored or anxious. The board game is a useful tool for teaching and learning the English grammar items, which could help reduce the learners' anxiety and motivate them in the learning process. Based on the survey conducted on the students' feedback after playing the board game, a huge majority of the participants responded that it is a useful, practical and fun tool for learning English grammar.

Keywords: English language teaching, grammar, board games

\section{Introduction}

English language learning can be a dreary and frustrating task, where constant effort is required to understand and apply this target language in order to master it. For weak students, learning the English grammar is even more daunting due to the complexity of grammar rules. Therefore, it is important that the right teaching approach is adopted so that grammar lessons can be effectively taught to the learners. For this reason, language games can serve as a way of teaching grammar, which can be incorporated as one of the activities in class. Language games are an invaluable tool as they offer the elements of fun and meaningfulness in language learning. They are also a means of motivating students to learn, as well as sustaining their interest and focus in the learning itself. When learning grammar is formatted into a game, it removes the monotony that seemingly relates to it. Instead, the game aspect comes to the forefront where students believe that they are playing a game. While engaging in the game, the teacher succeeds in getting them to learn without making them bored, hence, this could help reduce their anxiety levels. Krashen (1982) states that a learning situation that has a low affective filter can lessen anxiety and make the learners more comfortable. This encourages them to use language while playing the game, and thus, making learning more effective and meaningful (Littlewood, 1999).

\section{Problem Statement}

English grammar has its sets of complicated rules which present challenges for learners to master them. A large number 
of students struggle with these rules and could not completely understand many of the principles on their first or second reading. Most non-native students, such as the Malaysian students, are unable to apply the different parts of speech and types of tense in English accurately in their writing and speaking. In their attempt to apply the language skills, most grammar rules are normally confused, leading to common occurrences of erroneous structures in their speaking and writing. Therefore, it is essential to adopt an effective pedagogical approach in order to teach grammar effectively to the learners, especially those of the beginner or low proficiency level.

\section{Objective}

The main objective of this innovation project is to offer a creative and fun tool for teaching grammar to the beginner-level of English language learners, both in schools and higher learning institutions. For this reason, we have come out with a language game called Mind Your Grammar!. It is a board game that exclusively focuses on English grammar components, tailored for the beginner or low proficiency level of language learners. This is an innovation project that integrates fun, simplicity and practicality in order to motivate the students to learn grammar in class. We believe that by employing this game in English grammar lessons, it will create a platform for a meaningful exchange of communication for the students. Besides, using only the lecture style English materials in teaching grammar in class has quite a low effectiveness. When learning English grammar involves long hours of lecture in explaining grammar rules followed by completing the drills, the learners tend to lose their interest along the way. Hence, the Mind Your Grammar! board game can possibly offer a better option for motivating the students to learn.

\section{Literature Review}

According to Chang and Gogswell (2008), board games are a versatile asset in the classroom due to several benefits. They can be used to teach specific language forms and functions for diverse ESL/EFL contexts, age groups, proficiency levels, and content. In addition, they can also be adapted as a communicative activity in the classroom and applied as a concept for making one's own educational board game. Skehan (1998) also mentions that language board games promote communicative language learning through task completion, where the activities have some relationship to realworld contexts. Moreover, the use of games during teaching and learning helps the teacher to uphold the students' interest and focus during the class lesson. Games enable the teacher to create useful and meaningful contexts in language learning. When learners can react to the activity of the language game through their emotional expressions, the context clearly gives them a meaningful reason to learn the language (Wright, Betteridge \& Buckby, 2005). Dalton (n.d.) states that "Activities structured as games can provide concrete practice for learners, while reducing the tension and anxiety often encountered during the learning process." The author further argues that games can be beneficial for language learning in which they are normally designed in accordance with real-life activities. They offer the students with an opportunity to exercise real and meaningful language contexts while interacting in the game with others involved. Language games perform an immediate practical function where the teacher can set the embedded tasks which are interesting to the learners. Furthermore, Granger (1982) mentions that games enable the learners to participate in lively activities in class. Instead of just listening to the teacher explaining grammar rules during the class lesson, the students will do most of the talking while completing the tasks and interacting with others. Likewise, Clark (1982) asserts that games can be utilised as a means to assess and rehearse language lessons in a fun and entertaining atmosphere. By employing games as a pedagogical approach, the learners are often more motivated as compared to doing the desk tasks. While playing the games, the students' attention can be focused on the game activity, whereby subconscious learning of the language items will take place in them. Thus, this enables the learners to review and reinforce what they have learned in class.

Previous studies on the use of games for teaching grammar in class revealed the versatility of the language games and positive acceptance of the respondents on the subject matter. Besides, using games in language activities had been proven to produce positive results among the participants. For instance, Tengku Nazatul and Rahmah (2013) carried out a study involving 115 pre-TESL students of UiTM Pahang, Kuantan Campus, which aimed to investigate the advantages of employing board games to teach grammar. Utilising the experimental method for collecting data, the students were divided into two main groups: the control and experimental groups. The authors also used the survey method to elicit the responses on the treatment given to those in the experimental group. The results showed that the mean score for the experimental group was higher than the control group. It was revealed that the incorporation of board games in the treatment showed a significant difference between the two groups. The authors concluded that board 
games serve as a useful teaching tool that can be employed in grammar lessons as they offer various positive results in learners. In another research study conducted by Lawrence and Lawrence (2013), the authors examined the attitude of student teachers towards using grammar games for teaching English. The study employed the survey method for data collection, involving the student teachers doing their B. Ed. degree course in the Colleges of Education in Tirunelveli District. The study results revealed that a majority of the student teachers displayed a favourable attitude towards the utilisation of grammar games in teaching English at the secondary level. In another study done by Yolageldili and Arikan (2011), the authors looked into the efficiency of employing games in teaching grammar to young learners. In the study, the perceptions of 15 Turkish EFL teachers working in primary schools were gathered using the questionnaire method. The findings revealed that the Turkish EFL teachers acknowledged the important contribution of language games in classroom teaching. They also agreed that using games as a means of instructional approach is advantageous for teaching young learners.

\section{Methodology}

This innovative project employed the survey method for collecting data from the participants. The participants were comprised of the students taking the English proficiency courses at pre-diploma level in the MDAB programme of Universiti Teknologi MARA (UITM), Sarawak Campus. Precisely, there were 81 respondents in total, selected from the Pre-Diploma Programme of Business Management Faculty from Part 1, Session 2013/2014. Briefly, the MDAB programme (in its full term - Mengubah Destini Anak Bangsa Programme) is a programme inspired by the current Prime Minister, Datuk Seri Najib Razak. It was first established in UiTM in 2010 to provide educational opportunity for the qualified poor Malays and other bumiputeras from rural areas as well as urban areas, whose parents' monthly income is less than RM2,000. The programme is also offered at other UiTM branch campuses, namely, UiTM Sabah, UiTM Johor, UiTM Kelantan, UiTM Kedah, UiTM Negeri Sembilan, UiTM Pahang, UiTM Perlis and UiTM Terengganu. The students embarking in the programme have to complete the English proficiency courses, which will qualify them to proceed to the diploma level upon getting a pass of at least a $\mathrm{C}$ grade. The student selection for this study was based on the fact that their competence of the English language is generally low or at the beginner level, in which the board game is specially tailored for these target learners.

\section{Research Instrument}

A set of questionnaire was used in this survey study of the innovation project, which is divided into two parts: Section A and Section B. Section A consists of the respondents' profile (i.e. gender, age, mother tongue, hometown, and the SPM English result), while Section B comprises their feedback on the board game in accordance with 10 items stated in the questionnaire (see Table 1). The selected students were requested to play the game and give their responses by indicating their feedback in Section B of the questionnaire.

\section{Data Analysis}

The participants' responses on the language game's effectiveness and other attributes related to it were measured using the 5-point Likert scale (i.e. Strongly Agree, Agree, Neutral, Disagree, and Strongly Disagree). After playing the board game, they were given the questionnaire for them to indicate their responses. The results of the survey were analysed and converted into percentages, as shown in Table 1.

\section{Descriptions of the Mind Your Grammar! Board Game}

This language game comprises a game board, 500 cards marked with '?' (see Figure 2 for a sample of the card) that consist of grammar questions with multiple options, four game pieces (movers) representing the players, a dice, and an answer booklet with brief notes on grammar components. The board game illustrates a spiral comprising 100 spaces marked with numbers from 1 to 100 (See Figure 1). The spaces in the spiral consist of colourful images of rockets, comets and question marks (?), which we believe are appealing to the learners. 


\section{How to Play the Game}

The students were briefed on the purpose of the survey and how the game is played. The game can be played by 2-4 players. To start the game, each player takes turn to roll the dice, where the highest score will go first. Whenever a player lands on the space marked with '?', he/she needs to pick a card and answer the question on it (note: all the questions are related to grammar items for low proficiency level). If the answer is correct, the player will have a chance to roll another dice, however, if the answer is incorrect, he/she will miss a turn. If the player lands at the bottom of a rocket, he/she will move upward. On the contrary, if he/she lands at the tail of a comet, he/she will go downward. The game is similar to the concept of snake-and-ladder game, in which the player who reaches the space marked '100' first is the winner. It takes approximately 15 to 30 minutes to finish the game depending on the players' speed in answering the questions or reaching the winning space.

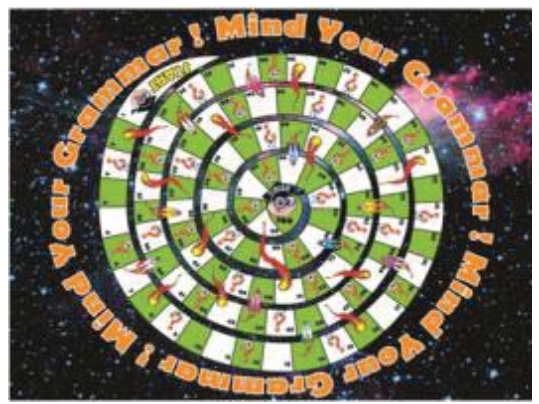

Figure 1: The game board
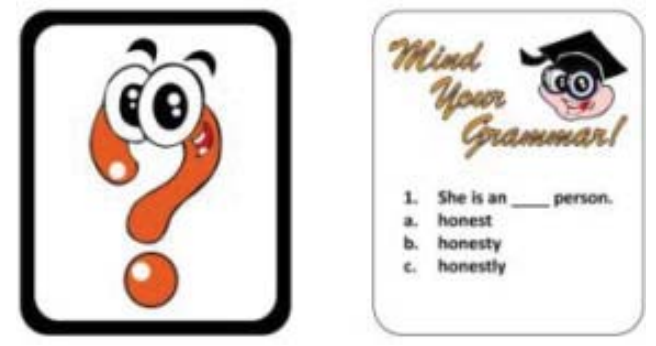

Figure 2: A sample of the question card

\section{Results and Discussion}

The findings from Section A of the questionnaire revealed that the respondents were comprised of $59.26 \%$ female and $40.74 \%$ male, and all of them are Sarawakian bumiputeras (i.e. Malays, Ibans, Bidayuhs, Kayans, Kenyahs and Kelabits). The respondents' ages ranged between 17-22 years old. In addition, a huge majority of the selected students were from rural areas, namely, Sri Aman, Mukah, Bintangor, Limbang, Belawai and Belaga. The findings also showed that a majority of the respondents acquired low grades in their English for Malaysian Certificate of Education (SPM), either grade $\mathrm{D}$ or $\mathrm{E}$.

On the other hand, as presented in Table 1, the findings from Section B of the questionnaire revealed that all the students enjoyed playing the board game, whereby $51.95 \%$ agreed and $48.15 \%$ strongly agreed on this survey item. As for survey item No. 2, 48.15\% of the students displayed their strong agreement. Likewise, the same percentage of the students (48.15\%) also revealed that they liked the colourful and fun features of the game. However, $3.7 \%$ of the respondents were neutral on this survey item. For survey item No. 3, a majority of the students (55.56\%) agreed that they had learned something new when playing the board game, followed by $44.44 \%$ who strongly agreed on this item. In addition, for survey item No. 4, a majority of the students (55.56\%) agreed that the board game could improve their 
grammar skills, while $44.44 \%$ expressed their strong agreement. As for survey item No. 5, a majority of the students (59.26\%) revealed their agreement that the board game had encouraged them to communicate with their friends in English. Meanwhile, $40.74 \%$ of the students strongly agreed on this item. For survey item No. 6, a majority of the students (55.56\%) stated that they agreed that using the board game was a fun way of learning English grammar, while $44.44 \%$ of the respondents displayed their strong agreement. With reference to survey item No. 7 , a majority of the students $(51.85 \%)$ strongly agreed that the questions in the board game are clear and can be easily understood, whereas $48.15 \%$ of the respondents agreed on this matter. For survey item No. 8, a majority of the participants (55.56\%) expressed their agreement that they would play the board game with their friends and family members in class or at home. Meanwhile, $37.04 \%$ of the students strongly agreed on this survey item. Nevertheless, $7.40 \%$ of the students were neutral on this matter. For survey item No. 9, a majority of the students $(51.85 \%)$ agreed that the board game is a practical and meaningful way of learning grammar items, whereas $48.15 \%$ of them expressed their strong agreement. Finally, for survey item No. 10, a majority of the students (51.85\%) stated that a grammar lesson should include grammar games as part of the activities, while $48.15 \%$ of the students agreed on this matter.

The results from the survey generally reveal the positive acceptance of the respondents to the board game. Students tend to regard learning English grammar as a difficult and boring subject due the complexity of the rules. However, with the right approach adopted, the teaching of grammar can be made fun and effective, such as by using grammar games. The students in this survey study of the innovation project clearly expressed their recognition of incorporating games in grammar lessons as a means of motivating them to learn. The activities in the game encourage them to interact with others in English, as well as improve their grammar skills while having fun with the language. The board game (i.e. Mind Your Grammar!) gives them a platform to review what they have learnt in their grammar lessons (Sultanova, 2011). Furthermore, the use of board games is more pleasurable and meaningful as learners can practise their grammar skills in their interaction with others. By using games in classroom lessons, "language use takes precedence over language practice, and in this sense games help bring the classroom to the real world, no matter how contrived they may be" Celce-Murcia and Macintosh (1979, p. 54). Besides, they provide students with an entertaining and relaxing learning atmosphere, and thus, this may reduce their stress and anxiety in learning grammar (Krashen, 1982).

Table 1: The respondents' feedback on Mind Your Grammar!

\begin{tabular}{|c|l|c|c|c|c|c|c|}
\hline \multirow{2}{*}{ No Survey Questions } & \multicolumn{2}{|c|}{ Strongly Agree } & \multicolumn{2}{c|}{ Agree } & \multicolumn{2}{c|}{ Neutral } \\
\cline { 3 - 9 } & & $\mathrm{n}$ & $\%$ & $\mathrm{n}$ & $\%$ & $\mathrm{n}$ & $\%$ \\
\hline 1 & I enjoy playing Mind Your Grammar!. & 39 & 48.15 & 42 & 51.85 & 0 & 0 \\
\hline 2 & I like the colourful and fun features of the board game. & 39 & 48.15 & 39 & 48.15 & 3 & 3.70 \\
\hline 3 & I learn something new when I play the board game. & 36 & 44.44 & 45 & 55.56 & 0 & 0 \\
\hline 4 & I can improve my grammar skills when I play the board game. & 36 & 44.44 & 45 & 55.56 & 0 & 0 \\
\hline 5 & $\begin{array}{l}\text { The board game encourages me to communicate in English } \\
\text { with friends. }\end{array}$ & 33 & 40.74 & 48 & 59.26 & 0 & 0 \\
\hline 6 & $\begin{array}{l}\text { Using the board game is a fun way of learning the grammar } \\
\text { items. }\end{array}$ & 36 & 44.44 & 45 & 55.56 & 0 & 0 \\
\hline 7 & $\begin{array}{l}\text { The questions in the board game are clear and can be easily } \\
\text { understood. }\end{array}$ & 42 & 51.85 & 39 & 48.15 & 0 & 0 \\
\hline 8 & $\begin{array}{l}\text { I will play the board game with my friends and family } \\
\text { members in class or at home. }\end{array}$ & 30 & 37.04 & 45 & 55.56 & 6 & 7.40 \\
\hline 9 & $\begin{array}{l}\text { The board game is a practical and meaningful way of learning } \\
\text { the grammar items. }\end{array}$ & 39 & 48.15 & 42 & 51.85 & 0 & 0 \\
\hline 10 & $\begin{array}{l}\text { A grammar lesson should include grammar games as part of } \\
\text { the activities. }\end{array}$ & 42 & 51.85 & 39 & 48.15 & 0 & 0 \\
\hline
\end{tabular}

Note: The total number of respondents was 81. The results for 'Disagree' and 'Strongly Disagree' are not displayed in the table above as the responses to these scales were all nil.

\section{Conclusion}

Languages games, such as the Mind Your Grammar! board game, are indeed a useful and practical tool which can be integrated in grammar lessons to assist language teaching and learning. They motivate learners and promote meaningful 
language use in a fun-filled environment. By using grammar games in language activities, teachers can improve their pedagogical approach and offer an effective strategy to the learners in teaching grammar.

\section{Acknowledgements}

We would like to express our deepest appreciation to UiTM Sarawak Campus for the financial support to participate and contest in the Invention, Innovation, Design and Expo 2013 (IIDEX2013), in which this innovation project has been awarded a gold medal. Our gratitude also goes to all the MDAB students who participated in the game and the survey.

\section{References}

Celce-Murcia, M ., \& McIntosh, L. (Eds.). (1979). Teaching English as a Second or Foreign Language. New York: Newbury House.

Chang, S. \& Gogswell, J. (2008). Using Board Games. TESOL 2008. Retrieved 19 June 2013 from www.rtmsd.org/.../Domain/57 /Using_Board_Games_Handout.doc

Clark, R.C. (ed.) (1982). Index Card Games for ESL. Brattleboro: Pro Lingua Associates.

Dalton, E. (n.d.). Language Learning Games: Why, When, and How. Southern New Hampshire University. Retrieved 5 May 2013 from http://gaeacoop.org/dalton/publications/LanguageGames.pdf

Granger, C. (1982). Play Games with English (Teacher's Book). London: Heinemann Educational Books Ltd.

Krashen, S. (1982). Principles and Practice in Second Language Acquisition. Oxford: Pergamon.

Lawrence, A. J. \& Lawrence, A. S. A (2013). Attitude of Student Teachers towards Using Grammar Games for Teaching English. International Journal on New Trends in Education and Their Implications, 4. Retrieved 20 June 2013 from http://academia.edu/2590689/attitude_of_student_teachers_towards_using_grammar_games_for_teaching_english

Littlewood, W. (1999). 'Second Language Teaching Methods' in B. Spolsky (Ed.). The Concise Encyclopedia Educational Linguistics. Oxford: Pergamon.

Skehan, P. (1998). A Cognitive Approach to Language Learning. Oxford: Oxford University Press.

Sultanova, D.T. (2011). The Use of Games in Learning. Proceeding of Uzbek-Indonesian Joint International Conference, 1. Retrieved 20 June 2013 from http://repository.gunadarma.ac.id//itstream/123456789/2504/1/THE\%20USE\%20OF\%20GAMES\%20IN \%20LEARNING\%20ENGLISH\%20GRAMMAR.pdf

Tengku Nazatul Shima Tengku Paris \& Rahmah Lob Yussof (2012). Enhancing Grammar Using Board Game. Procedia - Social and Behavioral Sciences. 68, 213-221. Retrieved 20 June 2013 from http://www.sciencedirect.com/science/journal/18770428/68

Wright, A., Betteridge, D., \& Buckby, M. (2005). Games for Language Learning (3rd ed.). New York: Cambridge University Press.

Yolageldili, G. \& Arikan, A. 2011). Effectiveness of Using Games in Teaching Grammar to Young Learners. Illköğretim Online, 10(1), 219-229, 2011. Retrieved 15 June 2013 from http://www.llkogretim-online.org.tr/vol10say1/v10s1m18.pdf 